University of New Hampshire

University of New Hampshire Scholars' Repository

2014

\title{
Hog Daddy and the Walls of Steel: Catch Shares and Ecosystem Change in the New England Groundfishery
}

Jennifer F. Brewer

The University of New Hampshire, jennifer.brewer@unh.edu

Follow this and additional works at: https://scholars.unh.edu/geog_facpub

Part of the Environmental Policy Commons, and the Nature and Society Relations Commons

\section{Recommended Citation}

Brewer, Jennifer F. 2014. "Hog Daddy and the Walls of Steel: Catch Shares and Ecosystem Change in the New England Groundfishery." Society and Natural Resources, 27(7), 724-741.

This Article is brought to you for free and open access by the Geography at University of New Hampshire Scholars' Repository. It has been accepted for inclusion in Geography Scholarship by an authorized administrator of University of New Hampshire Scholars' Repository. For more information, please contact 


\title{
Hog Daddy and the Walls of Steel: Catch Shares and Ecosystem Change in the New England Groundfishery
}

\author{
JENNIFER F. BREWER \\ Department of Geography, University of New Hampshire, Durham, \\ New Hampshire, USA
}

\begin{abstract}
The U.S. National Oceanic and Atmospheric Administration implemented marketbased fishery management in the New England groundfishery as catch shares, controlling aggregate harvests through tradable annual catch quotas allocated to fishing groups called sectors. Policy supporters assert that resulting markets raise conservation incentives. In compliance with the Magnuson-Stevens Fishery Conservation and Management Act, species assessments permit catch shares to replace more spatially and temporally specific constraints on fishing gear, time, areas, and daily harvest limits. Qualitative evidence from field interviews and participant observation questions the efficacy of catch shares. Fishing industry members observe that increased presence of large trawl vessels in previously protected areas damages fish subpopulations and benthic habitat. Regulatory bioeconomic models fail to consider these lay observations. The consequent inability of quota markets to recognize the materiality of human-environment relationships at the spatiotemporal scales of fishing activity, and to internalize associated externalities, may have devastating consequences for the fishery.
\end{abstract}

Keywords benthic habitat, cod (Gadus morhua), environmental markets, fish population dynamics, fishing gear impacts, Gulf of Maine, haddock (Melanogrammus aeglefinus), LEK, Massachusetts, privatization

Commercial fisheries provided some of the earliest thought experiments for the theoretical development of market-based solutions to environmental management problems (Gordon 1953; Scott 1955). Since practical application initiated in the 1970s, single- and multicase reviews of market-based fishery management point toward a series of ostensible successes, principally from the perspectives of aggregate economic profits, target fish species, and governmental administration (National Research Council 1999; Costello, Gaines, and Lynham 2008). A parallel series of studies finds that corresponding industry consolidation removes fishing-related activities from historically involved communities (National Research Council 1999; Copes and Charles 2004; U.S. Government Accountability Office [GAO] 2004; Pinkerton and Edwards 2010). Other authors question the purported causal link between market mechanisms and growth in target fish populations, and point to

Received 22 August 2012; accepted 21 June 2013.

Address correspondence to Jennifer F. Brewer, Department of Geography, University of New Hampshire, 102 Huddleston Hall, Durham, NH 03284, USA. E-mail: jennifer.brewer@, unh.edu 
ecological externalities such as impacts to nontarget fish populations and habitat (Copes 1986; Gibbs 2010; Emery et al. 2012). These differences in perceived benefits and risks also precipitate schisms within the fishing industry.

Despite these unsettled debates, leadership of the U.S. National Oceanic and Atmospheric Administration (NOAA) firmly embraced market-based fishery management in a 2009 national "catch share" policy and launched regional implementation efforts. The agency did so with encouragement and assistance from the Environmental Defense Fund, which had been lobbying on the issue for almost two decades (Environmental Defense Fund 1994; 2013). Following the 2006 lifting of a 1996 Congressional moratorium on some catch share programs, one of the fisheries NOAA targeted for conversion to market-based management was the New England groundfishery. Thus far, peer-reviewed and gray literature on the resulting groundfish catch share program have focused mainly on an administrative innovation whereby harvest shares were initially allocated to new management cooperatives called "sectors" instead of to individuals or firms in a more standard approach (Carroll 2012). Some authors point to the potential of these sectors and associated programs to ameliorate negative social and ecological impacts of quota markets, such as with research collaboration, alternative fish marketing, and quota banks supported by nonprofit and public entities (Holland and Wiersma 2010; Brinson, Lee, and Rountree 2011; Nature Conservancy 2011; Conathan 2012). In contrast, the present article suggests that the creation of an environmental market for fishery catch shares failed to consider spatiotemporal particularities of the socioecological system. Qualitative evidence indicates changes in fishing practices and associated ecosystem decline, observed by portions of the industry but thus far unaddressed by management. It demonstrates that policy implementation has averted public recognition of lay knowledge produced at the nexus of place-time-specific material interactions among fishing folk, fishing gear, and the marine environment.

\section{Research Methods}

Findings presented here are informed by field data collected since 1989, especially between 2002-2012. Analysis followed a generalized grounded theory approach, including textual and discourse analysis, data coding, countersampling, and iterative extraction of categories, themes, and findings (Strauss and Corbin 1990; Glaser 1994). The most directly relevant data collection was completed in 2010-2013. This included more than 20 hours of semistructured interviews with a combined snowball and stratified sample of 16 people, of which 13 hours were audio recorded. The aggregate fishing industry experience of these informants totals more than 300 years and spans gear types, boat sizes, and home states. Data also included 5 days of participant observation at seven public meetings, and 14 days of participant observation at private meetings, including less structured conversations with at least 27 people, 10 involved in the New England groundfishery and 17 familiar with catch share programs elsewhere. Interviews included present and past groundfishermen ${ }^{1}$ and their families, sector managers, staff of nonprofit organizations, present and past public officials, and scientists. Document review included hundreds of pages of government documents, nonprofit group materials, and media reports. The study draws less directly on additional structured and unstructured in-person interviews and less formal conversations undertaken for prior studies. These include more than 300 fishing industry members, public servants, nongovernmental organization 
(NGO) staff, scientists, and other coastal residents and professionals, sampled using snowball and stratified strategies. Other background data sources include 85 mail and phone survey responses from randomized samples of Maine fishermen; four focus groups in eastern Maine; participant observation at more than 40 public meetings and more than 50 nonpublic briefings, conferences, and project meetings in New England, Washington, DC, North Carolina, and Alaska; and more than four years of participant observation in marine resource management and policy arenas, and around fishing-dependent villages, households, vessels, and other businesses. ${ }^{2}$

\section{Markets and Fished Ecosystems}

Catch shares and related market-based management innovations are increasingly favored in fisheries policy worldwide (Beddington, Agnew, and Clark 2007; Costello, Gaines, and Lynham 2008). Potential public benefits and costs are discussed in numerous case studies, comparative analyses, and literature reviews (National Research Council 1999; Copes and Charles 2004; U.S. GAO 2004; Gibbs 2010; Emery et al. 2012; Grimm et al. 2012; Thébaud, Innes, and Ellis 2012; Pinkerton 2013). Reported outcomes vary with a range of factors relating to life histories and habitat of target and nontarget species, harvest technology, product markets, capital access, firm ownership and investment, informal social institutions, governance arrangements, data availability, and study methods. Advocates assert that catch shares create a "simpler and more efficient" management regime, eliminating the need for controls on fishing inputs, such as fishing gear, times, areas, boat sizes, and daily harvest totals, replacing these with economic incentives (Gulf of Maine Research Institute 2008, 4; Conathan 2012). Government agencies distribute as-yet-uncaught fish to fishing firms as quota, portions of the total allowable catch, generally calculated in relation to past boat landings and renewed annually. To accommodate normal variation and change in firm strategies and the marine ecosystem, quota transfers transpire by sale and lease. Quota values often rise rapidly after allocation, bringing windfall profits to initial recipients, and posing high barriers to aspiring boat owners with limited capital. Subsequent capital investment and legal takings provisions can prevent retraction of quota programs.

Biological models undergirding catch share implementation tend to neglect socioecological heterogeneity, lacking spatiotemporally explicit consideration of material interactions between humans and the marine environment (Clay 1996; Wilson, Acheson, and Kleban 1996; Walters et al. 2005; St. Martin 2006; Hilborn 2011). Standardized fish population assessment techniques used to set total allowable catches focus on the manipulation of target species datasets, isolating the execution of advanced statistical modeling work from routinized field data collection activities (Larkin 1977; Rose 1997). Despite ongoing experiments in ecosystem-based modeling, most assessments assume that present and future ratios of unharvested species quantities to subsequent survival and reproduction rates are similar to past ratios (Beddington, Agnew, and Clark 2007; cf. Christensen and Walters 2004; Tallis et al. 2010; Link 2012). They therefore project allowable catches from historical measures of fish populations and harvests. This seems logical as a mathematical equation, but it overlooks the potential for deviation from historic norms in any number of impinging variables. One cluster of overlooked variables involves oceanographic and climatic factors, such as water quality and temperature. Another involves other flora and fauna linked to target species through trophic or habitat 
interactions. The third cluster, most relevant to the case presented here, involves the how, where, and when of harvest activities, and associated impacts on fish survival and reproduction. This is the most intensively material site of fishing activity as human-marine interaction, the physical deployment of fishing technology. It is a site at which fishermen continually produce local knowledge at a fine scale of spatial and temporal specificity, observing innumerable variables pertinent to target species, fishing gear, and surrounding species and habitat. Extensive research demonstrates the potential utility of such local knowledge to management decision making (Wilson, Acheson, and Kleban 1996; Degnbol 2005; Haggan, Neis, and Baird 2007; Ruddle and Davis 2011).

NOAA social science capacity is growing (Abbott-Jamieson and Clay 2012) and produces increasingly substantive economic and social impact analyses, but per strictures of the Magnuson-Stevens Fishery Conservation and Management Act (FCMA) these analyses have minimal influence on regulatory decisions. Several underanalyzed variables are difficult to neatly quantify, but are directly relevant to the present discussion. These include firm sizes and structures, capital access and lending patterns, extensive fishing-related barter and kinship-dependent economies, and informal institutions (e.g., New England Fishery Management Council and National Marine Fisheries Service Northeast Fisheries Science Center 2003). Of greatest immediate significance, assessments do not consider socioecological drivers or implications of gear selection and deployment decisions aboard fishing boats. Some consolidation of fishing fleets is virtually universal under most catch share programs, despite any regulatory intentions (National Research Council 1999). This affects shore-side infrastructure development, financial control of quota, spatial distributions of fishing-related income and activity, and vertical integration of harvest and processing operations. A related risk remains virtually absent from the literature, and from public policy debates: the possibility that consolidated firms may escalate harmful ecological impacts of fishing activities as they achieve economies of scale. Attention to this possibility requires us to recognize two streams of ecological literature, one pointing toward habitat impacts of some fishing gear, and one investigating the spatiotemporal dynamics of fish populations.

Multiple studies document smoothing of rocky benthic contours by bottomtending fishing gear dragged behind boats, though it is less clear how such gear affects flat, sandy, or muddy bottom (National Research Council 2002). Other studies indicate that some fish populations, including groundfish species such as cod and haddock, comprise metapopulations (Reich and DeAlteris 2009; Skjæraasen et al. 2011), with some studies drawing explicitly on spatiotemporally specific industry observations (Bigelow 1924; Ames 2004). Subpopulations mix seasonally over large areas, then home to segregated spawning aggregations, demonstrating perennial site fidelity to shallow banks, rivermouths, or other features. Evolutionarily, this reproductive pattern can facilitate site-specific adaptation of subpopulations to highly local oceanographic conditions, and increase overall intraspecies genetic diversity. Loss of this spatialized diversity can decrease overall survival rates of juvenile fish, and increase species vulnerability to more generalized collapse (Kerr, Cadrin, and Secor 2010; Zemeckis et al. 2012).

These ecological literatures and corresponding industry observations pose a challenge to fishery managers, since gear impacts and metapopulations have not been quantified with sufficient statistical rigor to integrate into federal stock assessments, at least not convincingly enough to withstand courtroom scrutiny. Federal 
law and ongoing environmental lawsuits focus scientific assessment efforts on high levels of quantitative precision at the expense of empirical breadth (Walters et al. 2005; Longhurst 2010; Hilborn 2011). The groundfish case demonstrates how catch shares can aggravate this imbalance and may thereby incur long-term ecological damage.

\section{The Fishery and Its Assessment}

Groundfish are finfish living on or near the sea floor. In New England, commercially valued species managed together in the multispecies complex include cod, haddock, halibut, several flounders, pollock, hake, and redfish. Boats harvest groundfish with otter trawls, ${ }^{3}$ heavy net gear dragged behind vessels from 40 to more than $100 \mathrm{ft}$ long, or with gillnets or hooks, which can be set from smaller boats. They are based in harbors from Canada to the Mid-Atlantic states, including the largest ports of New Bedford and Gloucester, Massachusetts, and Portland, Maine (see Figure 1). Some firms own a few boats, and one in New Bedford owns 11, but most smaller boats belong to owner-operators, many of whom grew up in multigenerational fishing families.

Sustainable management of groundfish species has proven difficult. In the past, environmental groups have sued NOAA for failing to manage the resource in the public interest, and recent stock assessments indicate that the fishery is still

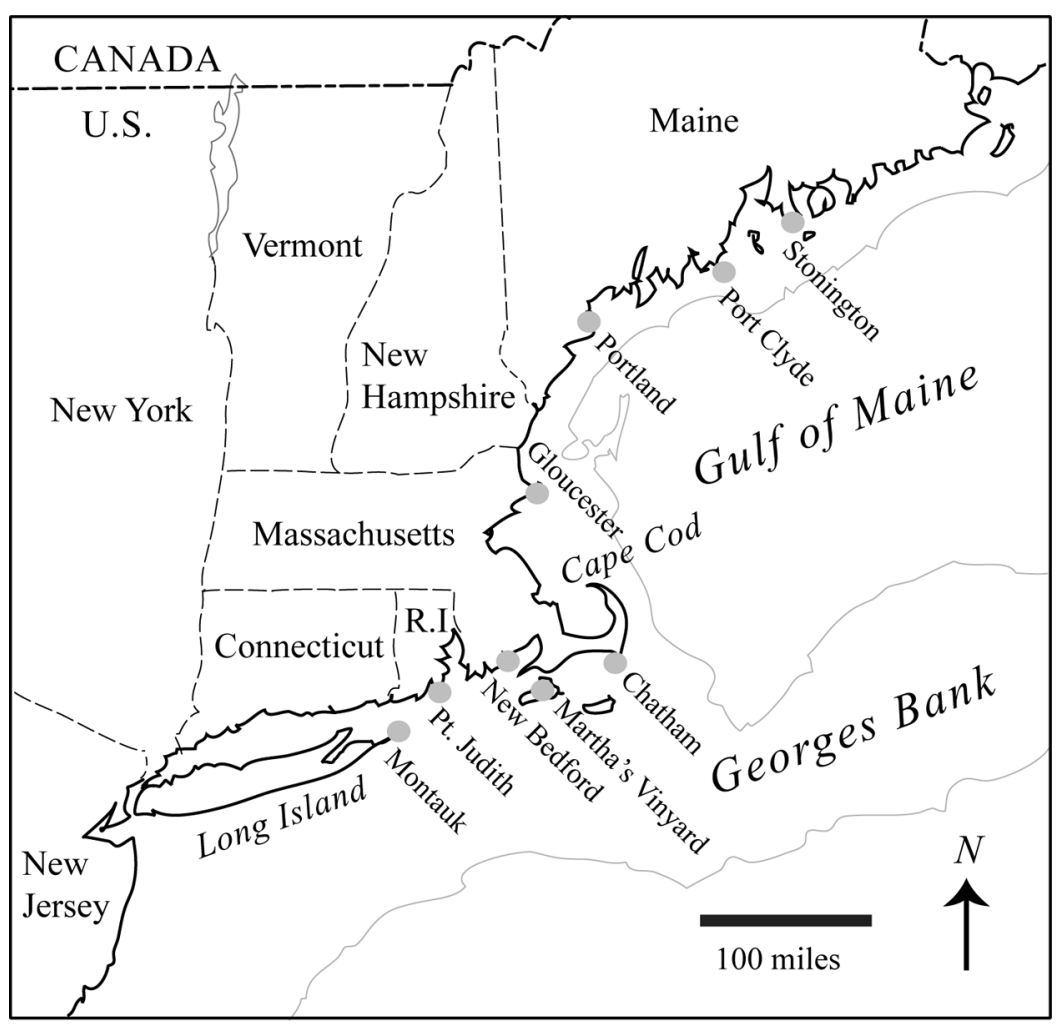

Figure 1. New England groundfishing region. 
not meeting rebuilding timelines that were implemented by Congress in 2006 at the urging of environmental groups. NOAA staff members establish biological and administrative parameters to ensure legal and policy compliance, but normally adopt regulations proposed by the New England Fishery Management Council, as intended by the Magnuson-Stevens Fishery Conservation and Management Act (FCMA), the primary federal fisheries law. The council is a federal advisory body including state fishery management agency designees and state-nominated, NOAAapproved representatives, mostly fishing industry members.

In the last two years, groundfish population assessments and anecdotal evidence indicate unprecedented population depletions simultaneous with the implementation of catch shares. In spring 2012, federal species assessments virtually mandated that portions of the fishery would shut down in the coming year. Following a mostly positive prior assessment, finding that Gulf of Maine cod were not overfished, pending cuts to cod, haddock, and yellowtail flounder quota reached or exceeded $70 \%$, with Gulf of Maine cod cuts reaching 90\%. The remainder of this article lays out one area of speculation about the cause of this crisis: a shift from more direct and spatiotemporally specific regulatory controls on fishing effort to annual quotas on harvest outputs. ${ }^{4}$ Admittedly, the present predicament is likely caused by some constellation of drivers, not one alone. Nonetheless, given fervent beliefs expressed by a significant portion of the industry, the concern seems plausible enough to merit more serious public consideration than it has received thus far.

\section{Shifting from Input to Output Controls}

One of the ostensible benefits of market-based quota management from the perspective of economists, and some fishermen and managers, is that it weakens the case for controls that focus on the day-to-day materiality of fishing activities, such as fishing gear, time, daily catches, and boat size (Copes 1979; National Research Council 1999; Gulf of Maine Research Institute 2008; Conathan 2012). Assuming that standard fish population assessments calculate annual allowable catches accurately, managers need not concern themselves much with where, when, or how harvest happens. Within relatively large spatial areas, such as Georges Bank, the Gulf of Maine, or southern New England, one dead pound of fish is calculated as one dead pound of fish, distinguished from others in the assessment mainly by estimated age and presumed reproductive capability. Particulars of fishing inputs such as gear technology, boat size, and fishing schedules and locations become mostly irrelevant. This apparent catch share benefit generally appeals to management agencies, believing they will no longer need to monitor, adjust, and enforce a slew of regulations, but can simply hold the industry to maximum annual output quotas. It also appeals to fishermen when led to believe that quotas will eliminate the need for other regulations.

Accordingly, when the New England Fishery Management Council implemented groundfish catch shares at NOAA urging, it lifted restrictions on fishing time, previously allocated as days-at-sea per boat per year. In recent years, the council had altered the accounting of fishing time to discourage inshore fishing by counting inshore days at a two-for-one ratio while offshore days remained as whole days. In the same vein, the council eliminated seasonal area closures that had been in place for more than a decade. These were called "rolling" closures because they closed and reopened each spring in staggered increments along the coast from Massachusetts to Maine. While ostensibly intended to simply reduce overall fishing mortality 
as accounted for in fishery assessments, the closures roughly followed the spawning schedules of key groundfish species as coastal waters warm seasonally from southwest to northeast. Under catch shares, the council also eliminated limits on per-trip species harvests, including cod limits that had ranged from 30 to 800 pounds per trip over the last decade. ${ }^{5}$

Shortly thereafter, large boats started plying waters just a few miles from shore, where closures and trip limits had previously deterred them. Fish populations were more abundant inshore than offshore, fuel costs were lower, and suddenly boats were allowed to fill their holds on each trip. NOAA confirmed for a reporter with the Gloucester Times that in a selected 3-day period of fall 2012, eight vessels larger than $70 \mathrm{ft}$ were legally operating on Middle Bank, less than an hour's steam from Massachusetts harbors. The reporter also confirmed with a sector manager that their large trawlers sometimes work inshore, though they spend the majority of their time offshore. Repeated sightings from smaller inshore boats sufficiently concerned the state's Department of Marine Fisheries that the agency has repeatedly asked the New England Fishery Management Council to curtail the new inshore effort, even though most of the large vessels operate from Massachusetts ports and are owned by Massachusetts constituents.

When they were in place, inshore area closures forced smaller boats to either cut fishing time or risk crew lives in deeper waters than their vessels can safely navigate in bad weather. Larger boats easily fished year-round in offshore waters beyond the seasonal closed areas. They now see incentives to come inshore, especially for cod, which aggregates inshore and generally brings good market prices at the dock. One small-boat fisherman conveyed the scale and biological impact of increased inshore effort:

We brought cod back... The fish are only here because we had seven months of rolling closures. We had trip limits as low as 30 pounds a day... while these [bigger] guys were fishing 12 months a year... So that's changed a lot, with a lot of big draggers working where big draggers never have been before. It's not uncommon to see the whole fleet of 90 foot draggers from Portland, Maine all the way to Gloucester working five miles off the coast [here]. One day I counted 17 of them. That had never, ever happened down here before. But it's an incentive for them... If they have 30,000 pounds to catch, why would they go to Georges [Bank] to catch it if they can catch it right inshore here? And they wouldn't have been able to do that before when we had trip limits of 1,500 pounds, 500 pounds. It wouldn't have been worth it for them to fish here. They would have gone to Georges to work ... amongst amongst other species. Instead they're coming in here and catching mostly just cod, and they can catch 30,000 pounds in a day or two.

\section{Inshore Fish Populations}

Many inshore fishermen believe they are witnessing detrimental impacts on fish populations as a result of this spatiotemporal change in harvest patterns. Not only does it concern them to observe that larger volumes of fish are being caught as they aggregate to spawn, but mobile ${ }^{6}$ fishing gear also scatters uncaught fish, perhaps 
interfering with spawning behavior. As one fisherman is fond of saying, "You might have trouble performing too, if there was a bulldozer in your bedroom." Larger boats have more horsepower, can handle more gear, and can tow areas where the gear of smaller trawlers would hang up and tear or risk capsizing the boat, especially in winter seas. On marginal weather days, if worse weather is pending, larger boats can now make shorter inshore trips, in a smaller window of time than a week-long trip to Georges Bank. One interviewee noted the greater capabilities of larger boats:

On a day like today when it's really blowing out, they don't have to come in; they can just keep on towing. They have enough power and stability to just tow at a constant speed even in rough weather, whereas a little boat just can't do it. But I don't think they're supposed to use anything larger than a 12 inch rockhopper on their nets. But there are ways to modify a 12 inch so you stack two and you basically have the same capability of a 24 inch roller, but legally it's a 12 inch. So they're getting around the gear restrictions and fishing inside... I know [NOAA] wants to maximize the catch per unit of effort, in which case those [big boats] are the greatest thing for it. But I think there's a point where you sort of have to regulate with a little bit of inefficiency there. Otherwise you're catching everything. You're not letting anything go.

Attentive fishermen describe very specific impacts to fish populations, compared to monthly migration histories. One gillnetter outlined the seasonal cycle of past winters:

Usually you can really catch a lot of codfish in December when I generally start. Then in January it gets a little harder. February is really slow. By the end of February, beginning of March, the haddock show up... [When] the codfishing dies out... I switch over and I go longlining for haddock.

He described the last year prior to catch shares, when inshore area closures and days-at-sea limits were still in place:

For all of February and all of March you couldn't get away from the codfish. They were everywhere. I never even put my longline gear on that year. And we could just go out and get 800 [pounds] of cod out of five nets.

In comparison, only two years later he finds it necessary to set 50 nets to catch fewer fish. "You wouldn't have dreamed of fishing that much gear three years ago." He notes that the size of the fish decreased, even between the first and second years of catch shares. With that shift, he lost the ability to fill his quota allocation with a smaller number of large, high-value fish. He now takes whatever legal fish he can find.

[That first year of catch shares,] I could have caught my whole allocation in three weeks if I really wanted to land a ton of fish. But I didn't. I set half the amount of gear and only set large mesh gear to bring in large 
codfish. It changed so fast. In year two it was so much harder. You couldn't use any large mesh gear anymore and catch big fish. You had to target what was left, the small fish. The whole thing makes me nauseous.

He went on to describe how the annual migrations seem to have declined:

Now I find, even last year, I was trying to catch my codfish still in February. Actually right up until the end I was just trying to finish my allocation. It's just a struggle. A lot of guys have kind of given up catching their cod for the year and are just trying to get rid of it now [by leasing it out to other boats]... And then the pollock which are usually here by Thanksgiving haven't even shown up yet this year. So the guys who really rely on those, if they don't show up here in the next three weeks, they're probably not going to show up at all.

While even unfished species populations can fluctuate greatly in abundance and size composition from one year to the next, another interviewee similarly noted that haddock has "become almost nonexistent to our inshore waters in the last few years." Despite the high market value of landed haddock, quota was trading for one or two cents a pound because fishermen can't find enough fish to fill their quota.

\section{Moving Habitat and Gear}

Fishermen also observe corresponding changes to fish habitat. One fisherman explained how different large trawlers are from smaller ones that have long plied these waters, in the way their fishing gear interacts with rocky seafloor:

The big boats are capable of running up and over these big piles [of rocks]...[M]y friends that are draggers, I tell them, "Oh, there's a lot of fish right where I am; they gotta be right on the edge of your tow." They go, "Yeah, we can't get any further to the east'erd." And I can see that 'cause I scallop also and I see the type of bottom that's there. And these big boats have come in and they've moved the bottom around, and now it's towable bottom. It used to be a nice rock pile, you know, with boulders scattered... And the big boats have gone through there enough times, and it's nothing but flat bottom now... Basically they're snowplowing it; they're pushing all the good stuff up out of the way. And that's habitat; it's very important.

Fishermen tell these stories in vivid physical detail, although suspended nutrients lend a dark, opaque color to Northwest Atlantic waters, preventing firsthand view of the ocean bottom. After decades on the water, they glean constant streams of ecological information by observing their own gear and catch, and the activities of other boats (Brewer 2013). One narrated how small trawlers can only fish on smooth bottom:

I've had spots that I jig on and that I longline ${ }^{7}$ on ... They're little areas of hard bottom that ever since I've been fishing it's been safe from the 
draggers. They can only get like a half a mile from me, then the bottom gets too hard for them to tow over... Last year I witnessed the big boats, they cut that half mile barrier down to a quarter mile, and within two or three days they were towing right up over the spot. These are big boats, boats [that] have never, ever in my history of fishing accessed that part of the bank before... going up and over it all the time, and they're destroying it. The little boats have never had the horsepower to get up and over the rocks like that.

He went on to explain how he knows this to be true, reading his sonar depthfinder to find special places to set out his gear:

I've seen it in person. I mean these are tiny little haunts that I fish on that are like the size of a car or truck. And I've seen those places, when you drive over them and you mark three or four feet up off bottom, I've seen those places completely get annihilated.

One story dates to some years before the area closure opening, but illustrates how irreplaceable these unseen benthic contours are in the livelihoods of small boat fishermen:

I saw it happen once with a dragger about ten or 12 years ago inshore to a spot that I specifically named Hog Daddy because that's what my sternman that caught a huge cod on the spot and goes "Hog Daddy!" He couldn't say anything [more]. That spot's one giant boulder that got moved, and just completely gone off of the edge.

As trawls drag over the bottom, they collide with any human-made objects they might encounter. Judging from interactions with fishing gear and shipwrecks, it seems reasonable to infer that more extensive habitat changes may be happening concurrently.

[Big boats are] literally towing down the state-federal line, three miles out. That's how close they are... where a lot of guys lobster. I know guys lost a ton of lobster traps. And all the inshore wrecks and hang ups that have been in the same spot forever are now getting towed and moved everywhere, so even the inshore small draggers are hanging up and just rimracking their gear in places where they've always been able to tow.

Another owner-operator noted:

There's this parade of 90 -footers going up and down ... and the gillnets are going for rides this way and that way and every other way. These guys are losing a lot of gear.

Some interviewees speculated that benthic changes wrought by large draggers may have even caused recent drownings. Two 40-odd-foot scallop boats went down in November and December 2012, the first just two miles from Cape Cod's 
Provincetown, after its gear snagged up on bottom, and the second 12 miles from the same harbor.

The two scallopers lately that one sunk and one tipped over, I wouldn't be surprised if they hung up on something that was moved and never there to begin with. Usually those mobile guys, they don't stray too far off their proven tows.

Crew are unlikely to survive a sinking or a capsized boat in the cold water of winter or early spring, and even less dangerous snags can cost fuel and short daytime work hours, so most small groundfish or scallop draggers stick to well-known pathways. As a gillnetter noted:

The small draggers are starting to tear up their gear on a regular basis where normally they know the bottom like the back of their hand and don't have to worry about it.

In addition to concerns about present-day catches, the cost of gear conflicts, and personal safety, many inshore fishermen are horrified that the long-term future of the fishery may be at stake. They fear that if they lose their businesses and quota allocations, a few of the largest firms will end up owning all the quota. In 2011, only a year into sector management, council staff publicly noted with quiet concern that three Massachusetts firms owned more than 40\% of Georges Bank winter flounder quota (New England Fishery Management Council 2011). The staff further revealed that in 2010, 26\% of Georges Bank haddock, 18\% of Georges Bank yellowtail, and $21 \%$ of Georges Bank cod were each controlled by three firms. More detailed information on quota ownership and transfer is protected by privacy laws. In 2012, one harvest sector controlled more than half the quota for several species, and the owner of 11 boats involved in groundfishing publicly announced that he had $\$ 50$ million invested in the fishery. Some see history repeating itself, comparing the present situation to the heyday of foreign fleets 40 years ago, before the FCMA.

Stocks can't take constant pressure. We went from the rolling closures and just an inshore fleet, the two coupled together seemed to be working great. Until all of a sudden it was like the Wild West: no rolling closures and everybody fishing in one little area. I don't think the fish stood a chance. Watch these big boats fish and they line right up, just like the old Russian pulse fishing ${ }^{8}$ that sort of got the whole Magnusson Act started.

\section{Pointing Fingers or Seeking Solutions?}

Despite feeling profound anger and sadness that a way of life may be slipping away from their families and home harbors, many inshore fishermen blame the regulatory situation more than big boat captains, who must respond to owner pressures to maximize profits on each fishing trip. One small-boat fisherman expressed his ambivalence:

It's hard because they're kind of forced to do what they're doing, so you can't really blame them too much. But on the other hand, all that 
conservation and all [those] daily limit[s] that all the small boats had to endure for so many years. And watch the stocks come back: "Wow this is great." The ones who really benefitted from that were the ones who caused the problem to begin with: the big boats. It's infuriating.

It is true that larger boats have higher fixed and operating costs. Many have less diversified business histories than small boats, so the firms have fewer income alternatives if their groundfish revenues fall. Most of the big boats in the New England fleet were built using funds and tax breaks provided by the federal government decades ago, when Congress wished to augment the domestic fleet to replace the evicted foreign boats. That sudden growth strained previously existing informal conservation norms and social networks that had long characterized the industry (Hennessey and Healey 2000; Acheson and Gardner 2011; Brewer 2012). In their defense, owners of larger boats point out that small boats are also capable of depleting fish populations. Untended gillnets continually entrap fish, which die or are eaten by seals if not harvested or released. With the elimination of trip limits, gillnetters may be motivated to set more nets and fill their quota quickly. With more nets, each might be tended less often. Other possible explanations for groundfish population decline have also circulated among scientists and industry members. Among them, discard rates of trip-limited species prior to catch shares may have exceeded current estimates. Discretionary handling of new federal data sources and outliers in existing data sets may have skewed recent population assessments. Climate change may cause warmer water species migrating northward to compete with resident species. Seal predation on groundfish may have increased. Imported herring used as lobster bait may transmit disease. Because most lobstermen can no longer afford groundfish permits, when they accidentally catch small fish in their traps, they often spear them as bait (Brewer 2012).

On the other hand, concerns about larger boats seem to be escalating. When they frequent inshore waters, the risk of collisions with smaller boats and gear rises. Justified or not, the risk may prevent smaller scale fishermen from speaking publicly on related issues at the New England Fishery Management Council. While many owners of large boats have a history of responsiveness to small-boat concerns, a few have a reputation for ruthlessness, and little incentive to maintain amiable relationships with small boats. One small-boat owner described his anxiety:

When you're a little 40-foot boat fishing with four fishing rods and you've got two 90 foot walls of steel on either side of you, [or] as a mobile gear fisherman, you're screwed if you have any type of issue.

Entanglement of deployed gear between a large and small trawler, even gear set on cables extending many meters behind the vessels themselves, can sink the smaller boat and crew within a matter of minutes.

We call it the first rule of the road: the big march on and the little sink ... It's a nasty dynamic that's developed. And a lot of times people that have made statements on the record on this kind of big boat, small boat issue - funny how you can get chased around the ocean by somebody who tries to tow you down. Everybody knows what everybody else does, and it has stifled discussion quite a bit where a lot of people are afraid to speak up... You 
figure you're gonna get run down the next day as word spreads among the large boat fleet that "hey, he spoke out against us; let's make his life miserable." It's like terrorism... You can't prove it... but I've seen it happen. I know it happens... When the sun starts to get eclipsed, you look up and there's three stories of steel right next to you... You can't outrun 'em... They don't have to say anything; they don't have to do anything. It's just the idea that I got within 50 feet here, the next time it could be 20. Perhaps you'd better keep your mouth shut when you go to meetings.

Regardless of the intentions of large-boat owners and captains with respect to fish populations, benthic habitat, and the safety and livelihoods of smaller vessels, their presence in newly opened areas is perfectly legal because the council and NOAA allow it. The FCMA includes only weak language on habitat protections, compared to explicit language guiding the use of population assessments to meet mandatory species rebuilding timelines and quantitative goals. Most involved environmental organizations support the concept of catch shares, in part because they set simple numerical standards by which to evaluate NOAA's performance, especially in court. In a November 2012 letter submitted to the council's Habitat Committee by the Conservation Law Foundation, a New England-based nonprofit that spearheaded fisheries conservation litigation in the 1990s, the organization noted that fishing-gear restrictions under consideration might trigger industry legal action, because they are not sufficiently supported by peer-reviewed science. Attention to gear impacts at the Habitat Committee level moves notoriously slowly, and traction at the council level is not apparent. Similarly, in December 2012 working-group reports, assessment scientists noted that spatialized models of New England cod populations might prove useful, but also cited studies supporting the status quo. Uncomfortable with the lack of clear scientific evidence, they instead awaited further analyses from the council's Scientific and Statistical Committee. One member of that committee found council consideration of ecosystem variables to be "on ice."

Not only has the council not devoted time to debate gear, habitat, and fish subpopulation issues, it has considered opening more closed areas. At a council meeting in December 2012, a large-boat fleet owner and former council member voiced the argument in terms of supporting working waterfronts, which are under gentrification pressure.

We have to mitigate and give the industry every opportunity it can to try to survive. The best way ... is to get pounds of fish over the dock. We... need to figure out ways to aggressively target the healthiest stocks we have. If we do that, it's my experience in watching this and trying to make this work, that we will have an impact on the less healthy stocks, in a positive way. In order to do that, we need to get access to those fish. We don't have access to that [more abundant] stock of haddock on a consistent basis. We get it when it decides to swim out [of a closed area]. We can't keep our markets going, we can't keep the infrastructure going that way. So all we want to do is get access to the healthiest stocks of fish we have.

He implied that his boats and others would shift effort from depleted fish populations to previously protected ones that should withstand the harvest pressure. Under 
the logic of catch shares, as long as boats do not exceed quota allocations, this is a fair proposal. Given the preceding observations from boats that have long fished recently opened areas, however, the prospect of more openings sounds ludicrous. In response, the council did not immediately open more areas, but designated some additional areas for access pending approval of individual sector requests by NOAA. NOAA responded by announcing its willingness to discuss the possibility of opening some areas (NOAA 2013). Even if the council wished to take emergency action and restore closures, trip limits, or days-at-sea, it would face legal challenges under the National Environmental Policy Act, which distinguishes between major regulatory actions that require public hearing timelines and formal environmental and social impact assessments, and regulatory adjustments that can be made without dedicated public review.

The only lasting solution to the fundamental conflict between the logic of market-based management and the material experience of fishing may lie in amendments to the FCMA to diversify the information streams used by managers and assessments. Doing so would be fraught with legal complexity, and would necessitate a level of policy discussion not yet taking place. It would require input from natural and social scientists with a range of expertise, the breadth of the fishing industry, and managers. New institutional arrangements would need to accommodate the generation and use of more integrative bodies of knowledge. Decision makers would have to concede that catch shares are not a panacea, and do not obviate regulatory responses to ecological and technological shifts.

\section{Conclusion}

Lifelong groundfishermen report detrimental changes in inshore fish populations and benthic habitat, and a rise of tensions between smaller and larger boats. These phenomena are not entirely new, but the severity and suddenness of recent reports correspond with the implementation of market-based catch share policy, and the removal of other controls such as harvest limits per fishing trip, area closures, and days-at-sea restrictions. Previously published evidence on catch shares is already mixed, and this case adds to the list of concerns. Justified or not, accusations abound among inshore groundfishermen that technological capabilities of the largest boats exceed ecosystem resilience. With some amount of industry consolidation being virtually unavoidable under market-based management, and as the standardized commodity of species quota replaces a broader suite of more materially specific regulatory options, concerns arise that any increasing prevalence of larger trawlers could invite unprecedented ecological damage.

The present article cannot offer decisive evidence that large boats cause ecological decline; it aspires only to document qualitative evidence provided by a particular segment of the industry, one with an interest in future access to a sustainable inshore fishery. As in any complex socioecological system, a nuanced understanding of fishery resilience can be difficult to discern without intensive field data collection using a range of methodologies. Instead, catch shares rely on predictive capacities of bioeconomic models uncoupled from the spatial and temporal particulars of humanenvironment relationships. Driving fishery assessments focus on readily quantifiable data about individual species, in relative isolation from quantitative and qualitative information about the intrinsically linked social and ecological contexts in which those species live, reproduce, and die. 
This case of apparent management failure reveals a dearth of attention to the spatiotemporal materiality of fishing activity. It seems that our government has chosen to grant a public resource to profit-seeking firms without due consideration of their physical operations - how they conduct daily business in the marine environment. Present policy removes knowledge production from the integrative site of lived human experience. It privileges presumed conservation incentives, profits, and administrative convenience over conflicting evidence collected by lifelong observers of the fished ecosystem. Of course industry knowledge is partial, contingent, and cannot be the sole basis for management decisions. Nonetheless, a substantial body of lay observation points toward the possibility of long term or permanent damage to a public trust resource, and may therefore merit more serious public consideration than it has received thus far.

\section{Acknowledgments}

I am greatly appreciative of the generous encouragement and critiques offered by the journal editors and anonymous reviewers. This research would not have been possible without anonymous informants who demonstrate trust in the ethics and progressive vision of the scientific process by sharing their personal observations.

\section{Notes}

1. The vast majority of New England fishers are male, and most female fishers call themselves fishermen, so the terms fisherman and groundfisherman are used here.

2. Many interviewees who buy or lease quota have larger financial investments at stake than at any time in the past. Those investments are at unprecedented immediate risk to the actions of other boats on the water, other quota holders in quota markets, other sector members and managers in sector decision processes, and other interests involved in regulatory arenas. To protect confidentiality, I provide only minimal details about each interviewee, such as home port, gear type, fishing experience, or boat size category. I generally distinguish smaller from larger boats at roughly $70 \mathrm{ft}$ in length, based principally on criteria offered by fishermen themselves.

3. Trawling is often called dragging, but drags also include gear made of metal rings interlaced to form net-like bags for harvesting scallops and other shellfish.

4. Fishery management literature borrows the terminology of inputs and outputs from bioeconomic models of industrialized agriculture (Finley 2009).

5. Daily species limits are not a perfect management tool. Like other kinds of catch quotas, they can lead to the discarding of already-dead fish.

6. Mobile gear is moved by boats, including trawls, drags, and other nets. This contrasts with fixed gear, which boats set in a one place at a time and includes hooks, gillnets, and traps.

7. Jigs and longlines are hook fishing technologies.

8. While huge harvest-processor vessels from several European and Asian countries fished within sight of U.S. coasts in the 1970s before "Americanization" of U.S. waters, Cold War tensions lent particular drama to the frequent presence of Soviet-bloc boats among them.

\section{References}

Abbott-Jamieson, S., and P. M. Clay. 2012. The long voyage to including sociocultural analysis in NOAA's National Marine Fisheries Service. Mar. Fish. Rev. 72(2):14-33.

Acheson, J. M., and R. Gardner. 2011. Modeling disaster: The failure of the management of the New England groundfish industry. North Am. J. Fisheries Manage. 31:1005-1018. 
Ames, E. P. 2004. The stock structure of Atlantic cod in the Gulf of Maine. Fisheries 29(1):1028.

Beddington, J. R., D. J. Agnew, and C. W. Clark. 2007. Current problems in the management of marine fisheries. Science 316(5832):1713-1716.

Bigelow, H. B. 1924. Fishes of the Gulf of Maine. Washington, DC: U.S. Department of Commerce, Bureau of Fisheries.

Brewer, J. F. 2012. Don't fence me in: Boundaries, policy, and deliberation in Maine's lobster commons. Ann. Am. Assoc. Geogr. 102(2):383-402.

Brewer, J. F. 2013. From personal experience to public participation: Social learning at the community fisheries action roundtable. Environ. Manage. 52(2):321-334.

Brinson, A., M.-Y. Lee, and B. Rountree. 2011. Direct marketing strategies: The rise of community supported fishery programs. Mar. Policy 35(4):542-548.

Carroll, S. 2012. Sector allocation: A misguided solution. Ocean Coastal Law J. 17(163):163-194.

Christensen, V., and C. J. Walters. 2004. Trade-offs in ecosystem-scale optimization of fisheries management policies. Bull. Mar. Sci. 74:549-562.

Clay, P. M. 1996. Management regions, statistical areas and fishing grounds: Criteria for dividing up the sea. J. Northwest Atlantic Fisheries Sci. 19:103-126.

Conathan, M. 2012. The future of America's first fishery: Improving management of the New England groundfishery. Washington DC: Center for American Progress.

Copes, P. 1979. The economics of marine fisheries management in the era of extended jurisdiction: The Canadian perspective. Am. Econ. Rev. 69:256-260.

Copes, P. 1986. A critical review of the individual quota as a device in fisheries management. Land Econ. 62(3):278-291.

Copes, P., and A. Charles. 2004. Socioeconomics of individual transferable quotas and community-based fishery management. Agric. Resource Econ. Rev. 33(2):171-181.

Costello, C., S. D. Gaines, and J. Lynham. 2008. Can catch shares prevent fisheries collapse? Science 321(5896):1678-1681.

Degnbol, P. 2005. Indicators as a means of communicating knowledge. ICES J. Mar. Sci. 62:606-611.

Emery, T. J., B. S. Green, C. Gardner, and J. Tisdell. 2012. Are input controls required in individual transferable quota fisheries to address ecosystem based fisheries management objectives? Mar. Policy 36(1):122-131.

Environmental Defense Fund. 1994. EDF is advocating reforms to reduce overfishing [press release]. New York, NY.

Environmental Defense Fund. 2013. Oceans policy and resources. http://www.edf.org/ oceans/oceans-policy-and-resources (accessed 20 May 2013).

Finley, C. 2009. The social construction of fishing, 1949. Ecol. Society 14(1):6.

Gibbs, M. T. 2010. Why ITQs on target species are inefficient at achieving ecosystem based fisheries management outcomes. Mar. Policy 33(1):83-89.

Glaser, B., ed. 1994. More grounded theory: A reader. Mill Valley, CA: Sociology Press.

Gordon, H. S. 1953. The economic theory of a common property resource: The fishery. $J$. Polit. Econ. 62:124-142.

Grimm, D., I. Barkhorn, D. Festa, K. Bonzon, J. Boomhower, V. Hovland, and J. Blau. 2012. Assessing catch shares' effects evidence from federal United States and associated British Columbian fisheries. Mar. Policy 36(3):644-657.

Gulf of Maine Research Institute. 2008. Groundfish spawning closure workshop: An initial conversation. Portland, ME.

Haggan, N., B. Neis, and I. G. Baird. 2007. Fishers' knowledge in fisheries science and management. Paris, France: UNESCO.

Hennessey, T., and M. Healey. 2000. Luwig's ratchet and the collapse of New England groundfish stocks. Coastal Manage. 28:187-213.

Hilborn, Ray. 2011. Future directions in ecosystem based fisheries management: A personal perspective. Fisheries Res. 108(2-3):235-239. 
Holland, D. S., and J. Wiersma. 2010. Free form property rights for fisheries: The decentralized design of rights-based management through groundfish "sectors" in New England. Mar. Policy 34(5):1076-1081.

Kerr, L. A., S. X. Cadrin, and D. H. Secor. 2010. Simulation modelling as a tool for examining the consequences of spatial structure and connectivity on local and regional population dynamics. ICES J. Mar. Sci. 67(8):1631-1639.

Larkin, P. A. 1977. An epitaph for the concept of maximum sustainable yield. Trans. Am. Fisheries Society 106(1):1-11.

Link, J. 2012. Ecosystem-based fisheries management: Confronting tradeoffs. Cambridge, UK: Cambridge University Press.

Longhurst, A. 2010. Mismanagement of marine fisheries. Cambridge, UK: Cambridge University Press.

National Oceanic and Atmospheric Administration. 2013. NOAA's intent on groundfish carryover in 2013. http://www.nero.noaa.gov/stories/2013/noaa_s_intent_on_groundfish_ carryover_in_2013.html (accessed 20 May 2013).

National Research Council. 1999. Sharing the fish: Toward a national policy on individual fishing quotas. Washington, DC: National Academies Press.

National Research Council. 2002. Effects of trawling and dredging on seafloor habitat. Washington, DC: National Academy Press.

Nature Conservancy. 2011. Permit banks: A strategy for viable and sustainable fisheries. Arlington, VA: The Nature Conservancy.

New England Fishery Management Council. 2011. Fleet diversity and accumulation limits in the groundfish fishery [staff presentation]. Workshop on accumulation limits and fleet diversity. Danvers, MA.

New England Fishery Management Council and National Marine Fisheries Service Northeast Fisheries Science Center. 2003. Draft amendment 13 to the northeast multispecies fishery management plan. Newburyport, MA.

Pinkerton, E. 2013. Alternatives to ITQs in equity-efficiency-effectiveness trade-offs: How the lay-up system spread effort in the BC halibut fishery. Mar. Policy 42:5-13.

Pinkerton, E., and D. N. Edwards. 2010. Ignoring market failure in quota leasing? Mar. Policy 34(5):1110-1114.

Reich, D. A., and J. T. DeAlteris. 2009. A simulation study of the effects of spatially complex population structure for Gulf of Maine Atlantic cod. North American J. Fisheries Manage. 29(1):116-126.

Rose, G. A. 1997. The trouble with fisheries science! Rev. Fish Biol. Fisheries 7:365-370.

Ruddle, K., and A. Davis. 2011. What is "ecological" in local ecological knowledge? Lessons from Canada and Vietnam. Society Nat. Resources 24:887-901.

Scott, A. 1955. The fishery: The objectives of sole ownership. J. Polit. Econ. 63(116):116-124.

Skjæraasen, J. E., J. J. Meager, Ø. Karlsen, J. A. Hutchings, and A. Fernö. 2011. Extreme spawning-site fidelity in Atlantic cod. ICES J. Mar. Sci. J. Conseil 68(7):1472-1477.

St. Martin, K. 2006. The impact of "community" on fisheries management in the US northeast. Geoforum 37(2):169-184.

Strauss, A., and J. Corbin. 1990. Basics of qualitative research: Grounded theory procedures and techniques. Thousand Oaks, CA: Sage.

Tallis, H., P. S. Levin, M. Ruckelshaus, S. E. Lester, K. L. McLeod, D. L. Fluharty, and B. S. Halpern. 2010. The many faces of ecosystem-based management: Making the process work today in real places. Mar. Policy 34(2):340-348.

Thébaud, O., J. Innes, and N. Ellis. 2012. From anecdotes to scientific evidence? A review of recent literature on catch share systems in marine fisheries. Front. Ecol. Environ. 10(8):433-437.

U.S. Government Accountability Office. 2004. Individual fishing quotas: Methods for community protection and new entry require periodic evaluation. Washington, DC: U.S. Government Accountability Office. 
Walters, C. J., V. Christensen, S. J. Martell, and J. F. Kitchell. 2005. Possible ecosystem impacts of applying MSY policies from single-species assessment. ICES J. Mar. Sci. 62:558-568.

Wilson, J. A., J. Acheson, and P. Kleban. 1996. Chaos and parametric management. Mar. Policy 20(5):429-438.

Zemeckis, D., W. Hoffman, M. Dean, M. P. Armstrong, D. Martins, and S. X. Cadrin. 2012. Spawning site fidelity and fine-scale population structuring of Atlantic cod in the Gulf of Maine: Cod stock structure workshop summary. Portsmouth, NH: Gulf of Maine Research Institute. 